\title{
Desarrollo de la legislación en discapacidad en Colombia
}

\author{
Development of the Legislation on Disability in Colombia
}

\author{
Clara Yamile Duarte Cuervo ${ }^{1}$ \\ Martha Lucía Osorno Posada²
}

Recibido: Abril 272012 • Enviado para modificación: Julio 182012 • Aceptado: Agosto 152012.

Duarte, C.; Osorno, M. (2013). Desarrollo de la legislación en discapacidad en Colombia. Revista Ocupación Humana, 13 (1), pp. 33-53.

\begin{abstract}
Resumen: Esta revisión se elaboró con el ánimo de establecer un panorama del desarrollo de la legislación relacionada con el tema de discapacidad en Colombia y de servir como referencia y base de análisis para los interesados en el tema. Se realiza una exploración de la normatividad en discapacidad y una categorización por ámbitos y por temas. Los documentos y normas identificadas en cada ámbito se presentan en tablas organizadas por categorías temáticas y en orden cronológico; para cada uno se especifican el tipo, la instancia o entidad que lo genera, el año de aprobación, su nombre o descripción general y el tema con el que se relaciona. Se emiten algunos comentarios sobre cada categoría a manera de balance, reconociendo los avances de la legislación colombiana en esta materia.
\end{abstract}

Palabras clave: Legislación, Discapacidad, Colombia.

Abstract: This thematic review was written in order to establish an overview in the development of the legislation on disability in Colombia, and to be a reference for those interested in this topic. An exploration and categorization on disability regulations by areas and topics was made. These categorizations are shown as tables in chronological order. For each regulation, the reader can identify its type, the authority that issued it, the sanction year, a general description and the topic to which each one is related. Some comments about each category are presented as a balance, recognizing the Colombian legislation progress in this field.

Key words: Legislation, Disability, Colombia.

\section{Introducción}

Puede considerarse que el interés de diferentes disciplinas del campo de la salud por la población con discapacidad, obedece por un lado, a la comprensión de dicha situación como resultado de enfermedades subyacentes que ameritan intervenciones clínicas o terapéuticas, esto desde una perspectiva médica (OMS, 2001). De otra parte, desde una perspectiva social, como producto del reconocimiento de que las condiciones sociales discapacitantes restringen a algunos individuos sus posibilidades de participar en la vida

\footnotetext{
${ }^{1}$ Terapeuta Ocupacional. Especialista en Administración de Salud Ocupacional. Candidata a Magister en Salud Pública. Grupo de Investigación Discapacidad, inclusión y sociedad. Universidad Nacional de Colombia. claradc2002@gmail.com

${ }^{2}$ Licenciada en Pedagogía Reeducativa. Magister en Lingüística y Español. Consultora independiente en discapacidad y derechos humanos. mlosornop@gmail.com.
} 
social (Gómez \& Cuervo, 2007) y en consecuencia de ser felices, desarrollar su potencialidades y lograr el bienestar, lo cual demanda acciones orientadas a lograr cambios sociales.

Considerando la existencia de una amplia legislación sobre discapacidad a partir de la cual las instancias gubernamentales pretenden dar respuesta a las problemáticas sociales de esta población e incidir sobre su bienestar, resulta pertinente que los profesionales interesados en el tema conozcan los desarrollos en esa materia. A continuación se presenta el resultado de una revisión temática que se espera sirva de referente a estudiantes y profesionales.

\section{Métodos}

Esta compilación fue realizada a partir de una exploración de las páginas web de las Naciones Unidas, de instancias gubernamentales, organizaciones no gubernamentales de personas con discapacidad, información facilitada por las entidades antes mencionadas y de documentos disponibles en archivos y medios digitales ${ }^{3}$. Tras la revisión de los documentos encontrados, se establecieron categorías temáticas dentro de las cuales se clasificaron y organizaron cronológicamente. En esta revisión se incluyen los documentos y normas a los que se les atribuye mayor importancia en las fuentes consultadas, ya sea por el conocimiento que de ellas tienen las poblaciones, los que en su contenido muestran avances en la comprensión y el abordaje de la discapacidad o por el mayor impacto que pueden te- ner sobre la vida y la inclusión social de esta población.

\section{Resultados}

\section{Ámbito internacional}

$$
\begin{array}{r}
\text { "Las libertades políticas y civiles } \\
\text { aumentan el conjunto de } \\
\text { capacidades de un individuo } \\
\text { y por tanto, su libertad de lograr } \\
\text { el bienestar". } \\
\text { (Cruz, 2005, p. 99). }
\end{array}
$$

Las declaraciones y tratados internacionales tienen por objeto comprometer a los Estados en la protección de los derechos humanos en general y de poblaciones vulnerables en particular, así como trazar lineamientos para la acción (Consejería Presidencial de Programa Especiales, 2012); estos han servido como principios y marco para la legislación colombiana sobre discapacidad. Cabe aclarar que las declaraciones presentan a los Estados recomendaciones generales para su accionar, mientras que los tratados son pactos internacionales preceptivos, vinculantes y con potencialidad coactiva, es decir que adquieren para los firmantes el carácter de norma, obligan al cumplimiento de lo firmado e implican acciones de monitoreo y de aplicación de sanciones.

En las fuentes revisadas se identificaron 22 documentos entre declaraciones, convenios, tratados, resoluciones y recomendaciones. De acuerdo a su contenido estos se clasificaron en cuatro temas: Derechos humanos en general (tabla 1), derechos humanos y discapacidad (tabla 2), trabajo, empleo y discapacidad (tabla 3), educación y

\footnotetext{
${ }^{3}$ Parte de la información contenida en las tablas referenciadas, fue extraída de Osorno (2009).
} 
discapacidad (tabla 4). Para el ámbito internacional no se encontró mucha variedad en lo referente a salud, acce- sibilidad, comunicación, cultura y deporte, temas que se incorporan en los contenidos de algunos de ellos.

Tabla 1. Legislación en discapacidad. Ámbito internacional. Derechos humanos en general.

\begin{tabular}{|c|c|c|c|c|}
\hline Tipo & Expedida por & Año & Nombre - Descripción de la norma & Tema \\
\hline Declaración & $\begin{array}{l}\text { Asamblea General } \\
\text { de las Naciones } \\
\text { Unidas - ONU }\end{array}$ & 1948 & $\begin{array}{l}\text { Declaración Universal de los Dere- } \\
\text { chos Humanos Establece la igualdad } \\
\text { de derechos como principio para to- } \\
\text { dos los seres humanos, la no discrimi- } \\
\text { nación y en particular los derechos al } \\
\text { trabajo, la seguridad social, la educa- } \\
\text { ción, la participación en la vida cultu- } \\
\text { ral en igualdad de condiciones. }\end{array}$ & $\begin{array}{l}\text { Derechos } \\
\text { Humanos }\end{array}$ \\
\hline Declaración & $\begin{array}{l}\text { Conferencia } \\
\text { Mundial de } \\
\text { Derechos } \\
\text { Humanos }\end{array}$ & 1993 & $\begin{array}{l}\text { Declaración y Programa de Acción de } \\
\text { Viena. Reafirma la obligación de los } \\
\text { Estados de velar por la igualdad de } \\
\text { derechos y la no discriminación. }\end{array}$ & $\begin{array}{l}\text { Derechos } \\
\text { Humanos }\end{array}$ \\
\hline
\end{tabular}

Las declaraciones incluidas en la tabla 1 , son la base para el reconocimiento de los derechos humanos en condiciones de igualdad y no discriminación, gozan de amplio reconocimiento por parte de los Estados en todo el mundo y se constituyen en he- rramientas fundamentales para la defensa y la protección de los derechos de grupos vulnerados. En la tabla 2, se incluyen las declaraciones referidas específicamente a los derechos de las personas con discapacidad.

Tabla 2. Legislación en discapacidad. Ámbito internacional. Derechos humanos y discapacidad.

\begin{tabular}{|c|c|c|c|c|c|}
\hline Tipo & Número & Expedida por & Año & $\begin{array}{c}\text { Nombre - Descripción } \\
\text { de la norma }\end{array}$ & Tema \\
\hline Declaración & & $\begin{array}{l}\text { Asamblea General de las } \\
\text { Naciones Unidas - ONU }\end{array}$ & 1971 & $\begin{array}{l}\text { Declaración de los De- } \\
\text { rechos del Retrasado } \\
\text { Mental*. }\end{array}$ & $\begin{array}{l}\text { Discapacidad } \\
\text { Intelectual }\end{array}$ \\
\hline Declaración & & $\begin{array}{l}\text { Asamblea General de las } \\
\text { Naciones Unidas - ONU }\end{array}$ & 1975 & $\begin{array}{l}\text { Declaración de los De- } \\
\text { rechos de los Impedi- } \\
\text { dos*. }\end{array}$ & General/Derechos \\
\hline Declaración & & $\begin{array}{l}\text { Asamblea General de las } \\
\text { Naciones Unidas - ONU }\end{array}$ & 1979 & $\begin{array}{l}\text { Declaración sobre los } \\
\text { Derechos de las Perso- } \\
\text { nas Sordo-Ciegas. }\end{array}$ & $\begin{array}{l}\text { Sordociegos/ } \\
\text { Derechos }\end{array}$ \\
\hline Resolución & $37 / 52$ & $\begin{array}{l}\text { Asamblea General de las } \\
\text { Naciones Unidas - ONU }\end{array}$ & 1982 & $\begin{array}{l}\text { Proclama el "Decenio } \\
\text { de Acción Mundial para } \\
\text { las Personas con Disca- } \\
\text { pacidad" y formula el } \\
\text { "Programa de Acción } \\
\text { Mundial para las Perso- } \\
\text { nas con Discapacidad". }\end{array}$ & General/Derechos \\
\hline
\end{tabular}




\begin{tabular}{|c|c|c|c|c|c|}
\hline Tipo & Número & Expedida por & Año & $\begin{array}{l}\text { Nombre - Descripción } \\
\text { de la norma }\end{array}$ & Tema \\
\hline Declaración & & $\begin{array}{l}\text { Conferencia Interguber- } \\
\text { namental Iberoamericana } \\
\text { sobre Políticas para Perso- } \\
\text { nas Ancianas y Personas } \\
\text { Discapacitadas }\end{array}$ & 1992 & $\begin{array}{l}\text { Declaración de Cartage- } \\
\text { na Sobre Políticas Inte- } \\
\text { grales para las Personas } \\
\text { con Discapacidad en el } \\
\text { Área Iberoamericana. }\end{array}$ & General/Derechos \\
\hline Resolución & $48 / 96$ & $\begin{array}{l}\text { Asamblea General de las } \\
\text { Naciones Unidas - ONU }\end{array}$ & 1993 & $\begin{array}{l}\text { Normas uniformes sobre } \\
\text { la igualdad de oportuni- } \\
\text { dades para las personas } \\
\text { con discapacidad. }\end{array}$ & General/ Derechos \\
\hline Tratado & & $\begin{array}{l}\text { OEA - Organización de } \\
\text { los Estados Americanos }\end{array}$ & 1999 & $\begin{array}{l}\text { Convención interameri- } \\
\text { cana para la eliminación } \\
\text { de todas las formas de } \\
\text { discriminación contra } \\
\text { las personas con disca- } \\
\text { pacidad. }\end{array}$ & General/Derechos \\
\hline Declaración & & $\begin{array}{l}\text { Cumbre Iberoamericana } \\
\text { de Jefes de Estado y de } \\
\text { Gobierno de los Países } \\
\text { Iberoamericanos }\end{array}$ & 2000 & $\begin{array}{l}\text { Declaración de Panamá: } \\
\text { "La Discapacidad un } \\
\text { Asunto de Derechos Hu- } \\
\text { manos: El Derecho a la } \\
\text { Equiparación de Opor- } \\
\text { tunidades y el Respeto a } \\
\text { la Diversidad". }\end{array}$ & General/Derechos \\
\hline $\begin{array}{l}\text { Documento } \\
\text { Técnico }\end{array}$ & & OMS & 2001 & $\begin{array}{l}\text { Clasificación Internacio- } \\
\text { nal del Funcionamiento, } \\
\text { la Discapacidad y la Sa- } \\
\text { lud - CIF. }\end{array}$ & $\begin{array}{l}\text { Clasificación/ } \\
\text { definición }\end{array}$ \\
\hline Convención & $56 / 168$ & $\begin{array}{l}\text { Asamblea General de las } \\
\text { Naciones Unidas - ONU }\end{array}$ & 2001 & $\begin{array}{l}\text { Convención Internacio- } \\
\text { nal Amplia e Integral } \\
\text { para la Protección y Pro- } \\
\text { moción de los Derechos } \\
\text { y la Dignidad de las Per- } \\
\text { sonas con Discapacidad } \\
\text { y protocolo facultativo. }\end{array}$ & General/Derechos \\
\hline Declaración & & OPS - OMS & 2004 & $\begin{array}{l}\text { Declaración de Mon- } \\
\text { treal sobre la Discapaci- } \\
\text { dad Intelectual. }\end{array}$ & $\begin{array}{l}\text { Discapacidad } \\
\text { Intelectual }\end{array}$ \\
\hline
\end{tabular}

Los documentos relacionados en la tabla 2 dejan ver un interés creciente por el tema, que evoluciona desde una perspectiva de salud a una de derechos; esto se refleja en la transformación en el uso de los términos ${ }^{4}$, que sugiere cambios en la comprensión del fenómeno de la discapacidad.
Llaman la atención las declaraciones expresas en relación con los derechos de las personas con discapacidad, pues especialmente en el caso de las convenciones de derechos, más que emitir nuevos lineamientos, reafirman lo establecido en otros documentos que definen los derechos para todas

\footnotetext{
${ }^{4}$ Los términos "retrasado mental", "impedidos", "inválidos" y "discapacitados" no son aceptados actualmente, pero se incluyen en las tablas pues hacen parte de las denominaciones de algunas de las declaraciones y documentos encontrados en esta revisión. Es importante tener en cuenta los paradigmas dominantes en los momentos históricos en que se emitieron tales declaraciones.
} 
las personas (Tromel citado por Correa, 2009).

Adicionalmente se evidencia un cambio importante, se pasa de una postura jurídica que estigmatiza y excluye a las personas con discapacidad de sus derechos y responsabilidades individuales y sociales, a una que los posiciona como sujetos de derechos. De otro lado, en ellas se reconoce el papel del Estado, al que se le asignan responsabilidades específicas en el abordaje del tema.

Los instrumentos jurídicos internacionales en los campos de trabajo y educación (tablas 3 y 4) son muestra del interés y la importancia, pero también de la complejidad que históricamente han representado los temas de inclusión educativa y laboral para los Estados, el sector productivo, la escuela, las personas con discapacidad y sus familias.

Cabe resaltar que los convenios y recomendaciones incluidos en la tabla 3, son considerados como referente normativo y de acción para nuestro país; en el caso del convenio 159 de 1983, fue ratificado por Colombia a través de la Ley 82 de 1988 (Consejería Presidencial de Programas Especiales, 2012).

Tabla 3. Legislación en discapacidad. Ámbito internacional. Trabajo, empleo y discapacidad.

\begin{tabular}{|l|l|l|l|l|l|}
\hline Tipo & No. & $\begin{array}{c}\text { Expedida } \\
\text { por }\end{array}$ & Año & $\begin{array}{l}\text { Nombre - Descripción } \\
\text { de la norma }\end{array}$ & Tema \\
\hline Recomendaciones & 99 & OIT & 1955 & $\begin{array}{l}\text { Adaptación y readapta- } \\
\text { ción profesional de los } \\
\text { discapacitados. }\end{array}$ \\
\hline Convenio & 111 & OIT & 1958 & $\begin{array}{l}\text { Relativo a la discrimina- } \\
\text { ción en materia de em- }\end{array}$ & Laboral \\
\hline pleo y ocupación.
\end{tabular}

En el campo de la educación, los documentos en la tabla 4 se incluyeron en virtud de su importancia para la transformación del abordaje de la educación de las personas con discapacidad, la cual ha transitado por la educación especial segregada, la educación integradora y recientemente la educación inclusiva.
Es en estas áreas, trabajo y educación, en los que las capacidades de transformación social de los países resultan más visibles, también las que mayores posibilidades de participación en la vida social y de desarrollo humano proporcionan a las personas con discapacidad. 
Tabla 4. Legislación en discapacidad. Ámbito internacional. Educación y discapacidad.

\begin{tabular}{|l|l|l|l|l|}
\hline \multicolumn{1}{|c|}{ Tipo } & $\begin{array}{c}\text { Expedida } \\
\text { por }\end{array}$ & Año & Nombre - Descripción de la norma & Tema \\
\hline Declaración & UNESCO & 1990 & $\begin{array}{l}\text { Declaración de Jomtien: Declaración Mun- } \\
\text { dial sobre Educación para Todos. }\end{array}$ & Educación \\
\hline Declaración & UNESCO & 1994 & $\begin{array}{l}\text { Declaración de Salamanca y Marco sobre } \\
\text { necesidades educativas especiales: integra- } \\
\text { ción y reconocimiento de la necesidad de } \\
\text { actuar para lograr "escuelas para todos". }\end{array}$ \\
\hline $\begin{array}{l}\text { Marco de } \\
\text { Acción }\end{array}$ & UNESCO & 2000 & $\begin{array}{l}\text { Educación para todos en las Américas. } \\
\text { Marco de acción regional. }\end{array}$ \\
\hline
\end{tabular}

\section{Ámbito nacional}

"En el Estado Social las personas que pertenecen a minorías tradicionalmente discriminadas y marginadas, o a sectores que están en circunstancias de debilidad manifiesta, tienen derecho a que el Estado remueva los obstáculos jurídicos que les impiden acceder a condiciones de igualdad, al goce efectivo de sus derechos, promueva prácticas de inclusión social y adopte medidas de diferenciación positiva para intentar, dentro de lo posible, la realización del principio de igualdad material". (Correa, 2009, p. 119).

Para este ámbito se seleccionaron 77 normas que fueron clasificadas temáticamente en nueve categorías: 1) discapacidad y derechos en Colombia (Tabla 5); 2) derechos de grupos específicos (Tabla 6); 3) atención en salud y discapacidad (Tabla 7); 4) trabajo, empleo y discapacidad (Tabla 8); 5) educación y discapacidad (Tabla 9); 6) accesibilidad (Tabla 10); 7) comunicación y discapacidad (Tabla 11); 8) cultura y discapacidad (Tabla 12); 9) deporte y discapacidad (Tabla 13).

Si bien la normatividad colombiana en discapacidad es más amplia, la se- lección se hizo en virtud de la importancia y visibilidad dada a estas normas en las fuentes revisadas; algunas de las que no se incluyeron están orientadas a reglamentar asuntos específicos, particularmente en lo relacionado con accesibilidad física ${ }^{5}$.

En términos del reconocimiento de derechos de los grupos considerados minoritarios, entre ellos las personas con discapacidad, la Constitución Política de 1991 es un hito en Colombia. No obstante el recurso constitucional disponible, las gestiones orientadas a garantizar los derechos a esta población siguen siendo insuficientes.

En coherencia con los principios de la nueva Constitución, se generaron normas como la Ley 100 de 1993, que contempló el aseguramiento de las personas con discapacidad considerándolas posibles beneficiarias del régimen subsidiado de salud (art. 157) y de las pensiones por invalidez o sobrevivientes. Esta ley también abrió la puerta a las reglamentaciones subsiguientes en materia de valoración del daño y la capacidad laboral y ocupacional como consecuencia de riesgos

\footnotetext{
${ }^{5}$ Nota de las autoras: Dado que este artículo fue escrito y aceptado en 2012, esta revisión no incluye la Ley 1616 de 2013 (Ley de salud mental) ni la Ley 1618 de 2013, "por medio de la cual se establecen disposiciones para garantizar el pleno ejercicio de los derechos de las personas con discapacidad".
} 
Tabla 5. Legislación en discapacidad. Ámbito nacional. Discapacidad y derechos en Colombia.

\begin{tabular}{|c|c|c|c|c|c|}
\hline Tipo & No & $\begin{array}{l}\text { Expedida } \\
\text { por }\end{array}$ & Año & Nombre - Descripción & Tema \\
\hline Decreto Ley & 74 & $\begin{array}{l}\text { Congreso de la } \\
\text { República }\end{array}$ & 1969 & $\begin{array}{l}\text { Aprobación de los pactos inter- } \\
\text { nacionales de derechos civiles y } \\
\text { políticos y derechos económicos, } \\
\text { sociales y culturales, ratificados en } \\
\text { Colombia en 1969, entraron en vi- } \\
\text { gor en } 1976 \text {. }\end{array}$ & $\begin{array}{l}\text { Derechos } \\
\text { humanos }\end{array}$ \\
\hline $\begin{array}{l}\text { Constitución } \\
\text { Política de } \\
\text { Colombia }\end{array}$ & & $\begin{array}{l}\text { Asamblea } \\
\text { Nacional } \\
\text { Constituyente }\end{array}$ & 1991 & $\begin{array}{l}\text { Algunos artículos relevantes: De- } \\
\text { rechos generales: } 13 \text { y } 42 \text {; Salud y } \\
\text { seguridad social: } 47,48 \text { y } 49 \text {; Edu- } \\
\text { cación: } 67 \text { y } 68 \text {; Trabajo: } 25 \text { y } 54 \text {; } \\
\text { Recreación y deporte: } 52 \text {; Cultura: } \\
\text { 70; Información: } 20 .\end{array}$ & $\begin{array}{l}\text { General/ } \\
\text { Derechos }\end{array}$ \\
\hline Ley & 100 & $\begin{array}{l}\text { Congreso de la } \\
\text { República }\end{array}$ & 1993 & $\begin{array}{l}\text { Crea el Sistema de Seguridad Social } \\
\text { Integral. Introduce la cobertura del } \\
\text { aseguramiento en caso de invali- } \\
\text { dez. Arts, } 42 \text { y } 43 \text { crea las juntas de } \\
\text { calificación de invalidez. }\end{array}$ & $\begin{array}{l}\text { Seguridad } \\
\text { Social Integral }\end{array}$ \\
\hline Decreto Ley & 2381 & $\begin{array}{l}\text { Presidencia de la } \\
\text { República }\end{array}$ & 1993 & $\begin{array}{l}\text { Se declara el } 3 \text { de diciembre como } \\
\text { el Día Nacional de las Personas con } \\
\text { Discapacidad. }\end{array}$ & $\begin{array}{l}\text { General/ } \\
\text { Derechos }\end{array}$ \\
\hline Ley & 361 & $\begin{array}{l}\text { Congreso de la } \\
\text { República }\end{array}$ & 1997 & $\begin{array}{l}\text { Establece mecanismos de inte- } \\
\text { gración social de las personas con } \\
\text { limitación y dictan otras disposicio- } \\
\text { nes. Adicionada con la ley } 1287 \text { de } \\
2009 \text { en lo que respecta a accesi- } \\
\text { bilidad. }\end{array}$ & $\begin{array}{l}\text { Integración } \\
\text { social }\end{array}$ \\
\hline Plan & $\begin{array}{c}\text { Plan } \\
\text { Nacional }\end{array}$ & $\begin{array}{l}\text { Departamento } \\
\text { Nacional de } \\
\text { Planeación }\end{array}$ & 1999 & $\begin{array}{l}\text { Plan Nacional de Atención a las } \\
\text { Personas con Discapacidad 1999- } \\
2002 \text {. }\end{array}$ & $\begin{array}{l}\text { General/ } \\
\text { Derechos }\end{array}$ \\
\hline Decreto & 276 & $\begin{array}{l}\text { Ministerio de } \\
\text { Salud }\end{array}$ & 2000 & $\begin{array}{l}\text { Modifica el decreto } 1068 \text { de } 1997 \text {, } \\
\text { respecto a la conformación del Co- } \\
\text { mité Consultivo Nacional para las } \\
\text { Personas con Limitación. }\end{array}$ & $\begin{array}{l}\text { Participación } \\
\text { social }\end{array}$ \\
\hline Decreto & 429 & $\begin{array}{l}\text { Ministerio de } \\
\text { Relaciones } \\
\text { Exteriores }\end{array}$ & 2001 & $\begin{array}{l}\text { Promulga protocolo adicional a } \\
\text { la Convención Americana sobre } \\
\text { DDHH en materia de derechos } \\
\text { económicos, sociales y culturales } \\
\text { suscrito en San Salvador. }\end{array}$ & $\begin{array}{l}\text { General/ } \\
\text { Derechos }\end{array}$ \\
\hline Ley & 762 & $\begin{array}{l}\text { Congreso de la } \\
\text { República }\end{array}$ & 2002 & $\begin{array}{l}\text { Aprueba la Convención interame- } \\
\text { ricana para la eliminación de todas } \\
\text { las formas de discriminación contra } \\
\text { las personas con discapacidad. }\end{array}$ & $\begin{array}{l}\text { General/ } \\
\text { Derechos }\end{array}$ \\
\hline Plan & $\begin{array}{c}\text { Plan } \\
\text { Nacional }\end{array}$ & $\begin{array}{l}\text { Departamento } \\
\text { Nacional de } \\
\text { Planeación }\end{array}$ & 2002 & $\begin{array}{l}\text { Plan Nacional de Discapacidad } \\
\text { 2002-2006. }\end{array}$ & $\begin{array}{l}\text { General/ } \\
\text { Derechos }\end{array}$ \\
\hline $\begin{array}{l}\text { Documento } \\
\text { técnico }\end{array}$ & $\begin{array}{l}\text { CONPES } \\
80\end{array}$ & $\begin{array}{l}\text { Departamento } \\
\text { Nacional de } \\
\text { Planeación }\end{array}$ & 2004 & Política Pública de Discapacidad. & $\begin{array}{l}\text { Atención e } \\
\text { Integración social }\end{array}$ \\
\hline Ley & 1145 & $\begin{array}{l}\text { Congreso de } \\
\text { Colombia }\end{array}$ & 2007 & $\begin{array}{l}\text { Organiza el Sistema Nacional de la } \\
\text { Discapacidad y dicta otras disposi- } \\
\text { ciones. }\end{array}$ & $\begin{array}{l}\text { General/ } \\
\text { Derechos }\end{array}$ \\
\hline Ley & 1346 & $\begin{array}{l}\text { Congreso de la } \\
\text { República }\end{array}$ & 2009 & $\begin{array}{l}\text { Aprueba la "Convención sobre los } \\
\text { Derechos de las Personas con Dis- } \\
\text { capacidad". }\end{array}$ & $\begin{array}{l}\text { General/ } \\
\text { Derechos }\end{array}$ \\
\hline
\end{tabular}


profesionales, frente a las cuales se proyectan modificaciones importantes en la actualidad.

Posteriormente entró en vigencia la Ley 361 de 1997, considerada en su momento, la ley marco en el tema de la discapacidad. Ésta es el punto de partida para reglamentaciones en aspectos particulares relacionados con el acceso y la participación de las personas con discapacidad en diferentes aspectos de la vida social, principalmente en aquellos que tienen que ver con la toma de decisiones sobre políticas públicas.

Después de 1997 varios acuerdos internacionales en materia de discapacidad han sido ratificados por Colombia (tabla 5), entre ellos se destaca la Convención de las Naciones Unidas sobre los Derechos de las Personas con
Discapacidad, aprobada mediante la Ley 1346 de 2009. La Convención en sí misma y su ratificación por parte de nuestro país revisten una especial importancia, no solo por el papel activo y decisivo que jugaron las personas con discapacidad en la formulación y promulgación de la misma, sino porque reafirma y posiciona los derechos humanos inherentes a esta población, realza su condición como sujetos jurídicos y cambia el enfoque actual hacia la población, lo cual implica transformaciones personales y sociales, y se hace transversal al ciclo vital (Covadonga, 2011). La ratificación además permite "ampliar el rango de protección y hacer exigibles las obligaciones que el tratado implica, que a todas luces son coherentes con los postulados constitucionales" (Correa,

Tabla 6. Legislación en discapacidad. Ámbito nacional. Derechos de grupos específicos.

\begin{tabular}{|c|c|c|c|c|c|}
\hline Tipo & No. & Expedida por & Año & $\begin{array}{c}\text { Nombre } \\
\text { Descripción de la norma }\end{array}$ & Tema \\
\hline Ley & 324 & $\begin{array}{l}\text { Congreso de la } \\
\text { República }\end{array}$ & 1996 & $\begin{array}{l}\text { Establece normas a favor de la po- } \\
\text { blación sorda, reconoce la lengua de } \\
\text { señas colombiana como propia de la } \\
\text { comunidad sorda del país. }\end{array}$ & Grupos/Sordos \\
\hline Decreto & 2369 & $\begin{array}{l}\text { Presidencia de la } \\
\text { República }\end{array}$ & 1997 & $\begin{array}{l}\text { Recomendaciones de atención a } \\
\text { personas con limitación auditiva. }\end{array}$ & Grupos/Sordos \\
\hline Ley & 982 & $\begin{array}{l}\text { Congreso de la } \\
\text { República }\end{array}$ & 2005 & $\begin{array}{l}\text { Establece normas tendientes a la } \\
\text { equiparación de oportunidades para } \\
\text { las personas sordas y sordociegas y se } \\
\text { dictan otras disposiciones. }\end{array}$ & $\begin{array}{l}\text { Grupos/Sordos } \\
\text { y sordociegos }\end{array}$ \\
\hline Ley & 1098 & $\begin{array}{l}\text { Congreso de la } \\
\text { República }\end{array}$ & 2006 & $\begin{array}{l}\text { Código de la infancia y la adolescen- } \\
\text { cia. Art. } 36 \text { : Derechos de los niños, } \\
\text { las niñas y los adolescentes con dis- } \\
\text { capacidad. }\end{array}$ & $\begin{array}{l}\text { Grupos/niños, } \\
\text { niñas y } \\
\text { adolescentes con } \\
\text { discapacidad }\end{array}$ \\
\hline Ley & 1275 & $\begin{array}{l}\text { Congreso de la } \\
\text { República }\end{array}$ & 2009 & $\begin{array}{l}\text { Establece lineamientos de política } \\
\text { pública nacional para las personas } \\
\text { que presentan enanismo y se dictan } \\
\text { otras disposiciones. }\end{array}$ & $\begin{array}{l}\text { Grupos/ } \\
\text { enanismo }\end{array}$ \\
\hline Ley & 1306 & $\begin{array}{l}\text { Congreso de la } \\
\text { República }\end{array}$ & 2009 & $\begin{array}{l}\text { Dicta normas para la protección de } \\
\text { personas con discapacidad mental } \\
\text { y establece el "régimen de la repre- } \\
\text { sentación legal de incapaces eman- } \\
\text { cipados". }\end{array}$ & $\begin{array}{l}\text { Grupos/ } \\
\text { personas con } \\
\text { discapacidad } \\
\text { mental }\end{array}$ \\
\hline
\end{tabular}


2009, p.118) y abre paso a debates en la legislación en torno al surgimiento de posibles nuevos derechos, entre ellos la accesibilidad, el ejercicio de la autonomía y de la capacidad jurídica. Por los aspectos antes descritos, la Ley 1346 de 2009 se convierte hoy en una herramienta imprescindible y fundamental cuando del reconocimiento y el respeto de los derechos de las personas con discapacidad, de los de sus familias y cuidadores se trata, e implica además para los actores comprometidos con el tema, un llamado a actuar en favor de su difusión y cumplimiento (Covadonga, 2011).

En lo que respecta a los desarrollos legislativos para grupos específicos (tabla 6), llama la atención que éstos son mayores para los grupos de personas con limitaciones visuales y auditivas. De acuerdo con Moreno (2007), la existencia desde los años
60 de los Institutos Nacionales para Sordos y para Ciegos, INSOR e INCI respectivamente, ha favorecido que se preste especial atención a las necesidades de esos grupos; si bien algunos consideran que esto es inequitativo, los representantes de esos grupos han defendido su permanencia. Ese desarrollo también podría entenderse como producto de la presión de las organizaciones civiles, que en el caso de las personas sordas, gozan de una cohesión significativa en el contexto nacional e internacional.

En lo que se refiere a la atención en salud, se encontró un número considerable de normas, se seleccionaron aquellas que organizan, engloban y caracterizan los servicios ofrecidos a esta población (tabla 7). La cantidad de normas encontradas, muestra la tradición del abordaje de la discapacidad desde la perspectiva médica.

Tabla 7. Legislación en discapacidad. Ámbito nacional. Atención en salud y discapacidad.

\begin{tabular}{|l|l|l|l|l|l|}
\hline Tipo & No. & Expedida por & Año & \multicolumn{1}{|c|}{$\begin{array}{l}\text { Nombre } \\
\text { Descripción de la norma }\end{array}$} & \multicolumn{1}{|c|}{ Tema } \\
\hline Decreto & 2358 & $\begin{array}{l}\text { Presidencia de la } \\
\text { República }\end{array}$ & 1981 & $\begin{array}{l}\text { Crea el Sistema Nacional de Rehabi- } \\
\text { litación y establece normas sobre la } \\
\text { educación, reeducación, readapta- } \\
\text { ción y reubicación Laboral. }\end{array}$ \\
\hline Resoluciónal \\
prón
\end{tabular}




\begin{tabular}{|c|c|c|c|c|c|}
\hline Tipo & No. & Expedida por & Año & $\begin{array}{c}\text { Nombre } \\
\text { Descripción de la norma }\end{array}$ & Tema \\
\hline Decreto & 2226 & $\begin{array}{l}\text { Ministerio de } \\
\text { Salud }\end{array}$ & 1996 & $\begin{array}{l}\text { Asigna al Ministerio de Salud la direc- } \\
\text { ción, orientación, vigilancia y ejecu- } \\
\text { ción de los planes y programas que } \\
\text { en el campo de la salud, se relacionen } \\
\text { con la tercera edad, indigentes, min- } \\
\text { usválidos y discapacitados. }\end{array}$ & Salud \\
\hline Resolución & 3165 & $\begin{array}{l}\text { Ministerio de } \\
\text { Salud }\end{array}$ & 1996 & $\begin{array}{l}\text { Lineamientos de atención en salud } \\
\text { para las personas con deficiencias, dis- } \\
\text { capacidades y minusvalías. }\end{array}$ & Salud \\
\hline Acuerdo & 72 & $\begin{array}{l}\text { Consejo } \\
\text { Nacional de } \\
\text { Seguridad Social } \\
\text { en Salud }\end{array}$ & 1997 & $\begin{array}{l}\text { Define el plan de beneficios para el } \\
\text { régimen subsidiado para la atención } \\
\text { en rehabilitación funcional de perso- } \\
\text { nas con deficiencia o discapacidad. } \\
\text { Derogado por el art. } 96 \text { del acuerdo } \\
415 \text { de } 2009 \text {. }\end{array}$ & Salud \\
\hline Acuerdo & 77 & $\begin{array}{l}\text { Consejo } \\
\text { Nacional de } \\
\text { Seguridad Social } \\
\text { en Salud }\end{array}$ & 1997 & $\begin{array}{l}\text { Define como priorizables para la afi- } \\
\text { liación al régimen subsidiado a pobla- } \\
\text { ción con limitaciones físicas, psíquicas } \\
\text { y sensoriales. }\end{array}$ & Salud \\
\hline Resolución & 2178 & $\begin{array}{l}\text { Ministerio de } \\
\text { Salud }\end{array}$ & 1998 & $\begin{array}{l}\text { Complementa la ley } 361 / 97 \text { que seña- } \\
\text { la la necesidad de identificación de las } \\
\text { personas con discapacidad en el carné } \\
\text { de afiliación al SGSSS. }\end{array}$ & Salud \\
\hline Resolución & 238 & $\begin{array}{l}\text { Ministerio de } \\
\text { Salud }\end{array}$ & 1999 & $\begin{array}{l}\text { Normas técnicas científicas y adminis- } \\
\text { trativas con requisitos esenciales para } \\
\text { prestación de servicios de salud inclui- } \\
\text { dos psiquiatría y las terapias. }\end{array}$ & Salud \\
\hline Ley & 643 & $\begin{array}{l}\text { Congreso de la } \\
\text { República }\end{array}$ & 2001 & $\begin{array}{l}\text { Régimen propio del monopolio rentís- } \\
\text { tico de juegos de suerte y azar. Esta- } \\
\text { blece destinar el } 4 \% \text { a la afiliación al } \\
\text { régimen subsidiado a "discapacitados, } \\
\text { limitados visuales y salud mental". }\end{array}$ & Salud \\
\hline
\end{tabular}

En relación con el tema de trabajo y empleo (tabla 8), cabe destacar el seguimiento de las recomendaciones de la OIT sobre readaptación profesional y empleo. Así mismo la Ley 443 de 1998 y sus decretos reglamentarios relacionados con el ingreso a la carrera administrativa, muestran avances en materia de oportunidades de inclusión laboral; no obstante, desconocen la importancia de asegurar a las personas con discapacidad los ajustes razonables que permitan su participación en verdadera igualdad de condiciones.
En lo atinente a educación, la tabla 9 muestra una dinámica prolífica a partir de la promulgación de la Ley 115 de 1994, que instituyó en el país la integración escolar dejando atrás la educación especial segregada. Estos desarrollos probablemente también puedan atribuirse a la presión de las organizaciones de personas y familias de personas con limitaciones físicas y sensoriales y a los retos que tal integración supone para el sistema educativo. Moreno señala que estas normas han enfatizado más "en quienes tienen que integrarse" que en "los procesos 
Tabla 8. Legislación en discapacidad. Ámbito Nacional. Trabajo, empleo y discapacidad.

\begin{tabular}{|c|c|c|c|c|c|}
\hline Tipo & No & Expedida por & Año & $\begin{array}{c}\text { Nombre } \\
\text { Descripción de la Norma }\end{array}$ & Tema \\
\hline Ley & 82 & $\begin{array}{l}\text { Congreso de la } \\
\text { República }\end{array}$ & 1988 & $\begin{array}{l}\text { Aprueba el Convenio } 159 \text { sobre la re- } \\
\text { adaptación profesional y el empleo de } \\
\text { personas inválidas, adoptado por la Con- } \\
\text { ferencia General de la OIT en } 1983 \text {. }\end{array}$ & Laboral \\
\hline Ley & 2177 & $\begin{array}{l}\text { Presidencia de la } \\
\text { República }\end{array}$ & 1989 & $\begin{array}{l}\text { Desarrolla la Ley } 82 \text { de } 1988 \text {, sobre re- } \\
\text { adaptación profesional y el empleo de } \\
\text { personas inválidas. }\end{array}$ & Laboral \\
\hline Decreto & 970 & $\begin{array}{l}\text { Presidencia de la } \\
\text { República }\end{array}$ & 1994 & $\begin{array}{l}\text { Convenio sobre readaptación profesio- } \\
\text { nal y el empleo de personas inválidas. }\end{array}$ & Laboral \\
\hline Decreto & 692 & $\begin{array}{l}\text { Ministerio de } \\
\text { Trabajo y } \\
\text { Seguridad Social }\end{array}$ & 1995 & $\begin{array}{l}\text { Manual único de calificación de invali- } \\
\text { dez. }\end{array}$ & Laboral \\
\hline Ley & 443 & $\begin{array}{l}\text { Congreso de la } \\
\text { República }\end{array}$ & 1998 & $\begin{array}{l}\text { Junto a los decretos reglamentarios } 1571 \\
\text { y } 1572 / 98 \text { se expiden normas sobre ca- } \\
\text { rrera administrativa y medidas para ga- } \\
\text { rantizar igualdad de oportunidades en } \\
\text { el acceso a la misma a los ciudadanos } \\
\text { con limitaciones físicas y garantizarles } \\
\text { un trabajo acorde con sus condiciones } \\
\text { de salud. }\end{array}$ & Laboral \\
\hline Decreto & 1128 & $\begin{array}{l}\text { Ministerio de } \\
\text { Trabajo y } \\
\text { Seguridad Social }\end{array}$ & 1999 & $\begin{array}{l}\text { Reestructura el Ministerio y le asigna fun- } \\
\text { ciones en tema de discapacidad. }\end{array}$ & Laboral \\
\hline Decreto & 917 & $\begin{array}{l}\text { Presidencia de la } \\
\text { República }\end{array}$ & 1999 & $\begin{array}{l}\text { Modifica el decreto } 692 / 95 \text { - Manual } \\
\text { Único de Calificación de Invalidez, esta- } \\
\text { blece que la calificación pueden hacerla } \\
\text { las EPS y las ARS. Con el fin de garantizar } \\
\text { el acceso a derechos. }\end{array}$ & Laboral \\
\hline
\end{tabular}

sociales, administrativos, logísticos y tecnológicos requeridos para que esta integración sea exitosa" (Moreno, 2007, p. 73).

En el tema de accesibilidad física (tabla 10) se han hecho desarrollos importantes, especialmente desde la entrada en vigencia de la Ley 361 de 1997; Ilama la atención el interés en el tema de vivienda en los últimos años. No obstante, en la implementación de estas normas aún falta mucho por recorrer, la presencia de barreras arquitectónicas sigue siendo una condición que aumenta el nivel de discapacidad de las personas con limitaciones Colombia.
Las normas dirigidas a disminuir las dificultades de acceso a diferentes espacios de la vida cotidiana para aquellas personas con limitaciones para comunicarse de manera convencional, son particularmente importantes en la disminución de la discapacidad (Tabla 1). Las personas con limitaciones auditivas, visuales y cognitivas suelen tener dificultades en este aspecto, no obstante, las normas existentes no las consideran a todas en su diversidad y una vez más, los logros reflejan la capacidad de movilización social de los grupos más cohesionados.

Los convenios internacionales en materia de derechos de las personas 
Tabla 9. Legislación en discapacidad. Ámbito nacional. Educación y discapacidad.

\begin{tabular}{|c|c|c|c|c|c|}
\hline Tipo & No & Expedida por & Año & $\begin{array}{c}\text { Nombre } \\
\text { Descripción de la norma }\end{array}$ & Tema \\
\hline Ley & 115 & $\begin{array}{l}\text { Ministerio de } \\
\text { Educación }\end{array}$ & 1994 & $\begin{array}{l}\text { Ley General de Educación. Capítulo I. } \\
\text { Educación para personas con limitacio- } \\
\text { nes o capacidades excepcionales. }\end{array}$ & $\begin{array}{l}\text { Educación. } \\
\text { Integración } \\
\text { escolar }\end{array}$ \\
\hline Decreto & 369 & $\begin{array}{l}\text { Presidencia de la } \\
\text { República }\end{array}$ & 1994 & $\begin{array}{l}\text { Modifica la estructura y funciones del } \\
\text { Instituto Nacional para Ciegos - INCl-. }\end{array}$ & $\begin{array}{l}\text { Educación } \\
\text { Ciegos }\end{array}$ \\
\hline Decreto & 2082 & $\begin{array}{l}\text { Presidencia de la } \\
\text { República }\end{array}$ & 1996 & $\begin{array}{l}\text { Reglamenta la atención educativa para } \\
\text { personas con limitaciones o capacida- } \\
\text { des excepcionales. }\end{array}$ & Educación \\
\hline Decreto & 3011 & $\begin{array}{l}\text { Presidencia de la } \\
\text { República }\end{array}$ & 1997 & $\begin{array}{l}\text { Adecuación de instituciones en progra- } \\
\text { mas de educación básica y media de } \\
\text { adultos con limitaciones. }\end{array}$ & $\begin{array}{l}\text { Educación } \\
\text { adultos }\end{array}$ \\
\hline Decreto & 672 & $\begin{array}{l}\text { Presidencia de la } \\
\text { República }\end{array}$ & 1998 & $\begin{array}{l}\text { Relacionado con la educación de niños } \\
\text { sordos y la lengua de señas. }\end{array}$ & $\begin{array}{l}\text { Educación } \\
\text { sordos }\end{array}$ \\
\hline Decreto & 1509 & $\begin{array}{l}\text { Ministerio de } \\
\text { Educación } \\
\text { Nacional }\end{array}$ & 1998 & $\begin{array}{l}\text { Disposiciones para el ejercicio de la su- } \\
\text { pervisión y la vigilancia que debe cum- } \\
\text { plir el INCI en relación con las entida- } \\
\text { des y organizaciones de y para ciegos. }\end{array}$ & $\begin{array}{l}\text { Educación } \\
\text { ciegos }\end{array}$ \\
\hline $\begin{array}{l}\text { Norma } \\
\text { técnica }\end{array}$ & 4595 & $\begin{array}{l}\text { ICONTEC } \\
\text { Ministerio de } \\
\text { Educación } \\
\text { Nacional }\end{array}$ & $\begin{array}{l}1999 / \\
2006\end{array}$ & $\begin{array}{l}\text { Establece los requisitos para el planea- } \\
\text { miento y diseño de nuevas instalacio- } \\
\text { nes escolares, acogiendo los temas de } \\
\text { accesibilidad, seguridad y comodidad. }\end{array}$ & Educación \\
\hline $\begin{array}{l}\text { Norma } \\
\text { técnica }\end{array}$ & 4596 & $\begin{array}{l}\text { ICONTEC } \\
\text { Ministerio de } \\
\text { Educación } \\
\text { Nacional }\end{array}$ & $\begin{array}{l}1999 / \\
2006\end{array}$ & $\begin{array}{l}\text { Requisitos para diseñar y desarrollar un } \\
\text { sistema integral de señalización en las } \\
\text { instituciones educativas, que contribu- } \\
\text { ya a la seguridad y fácil orientación de } \\
\text { los usuarios, dispone el uso de señales } \\
\text { para personas con discapacidad. }\end{array}$ & Educación \\
\hline $\begin{array}{l}\text { Norma } \\
\text { técnica }\end{array}$ & $\begin{array}{l}4732 y \\
4733\end{array}$ & $\begin{array}{l}\text { ICONTEC } \\
\text { Ministerio de } \\
\text { Educación } \\
\text { Nacional }\end{array}$ & 1999 & $\begin{array}{l}\text { Requisitos y ensayos a pupitres y sillas } \\
\text { destinadas para uso de los estudiantes } \\
\text { con parálisis cerebral y en sillas de rue- } \\
\text { das. }\end{array}$ & $\begin{array}{l}\text { Accesibilidad } \\
\text { (educación) }\end{array}$ \\
\hline Resolución & 2565 & $\begin{array}{l}\text { Ministerio de } \\
\text { Educación }\end{array}$ & 2003 & $\begin{array}{l}\text { Reglamenta los servicios de educación } \\
\text { para los niños con necesidades educati- } \\
\text { vas especiales. }\end{array}$ & Educación \\
\hline Ley & 1297 & $\begin{array}{l}\text { Congreso de la } \\
\text { República }\end{array}$ & 2009 & $\begin{array}{l}\text { Regula lo atinente a los requisitos y } \\
\text { procedimientos para ingresar al servicio } \\
\text { educativo estatal en las zonas de difícil } \\
\text { acceso, poblaciones especiales o áreas } \\
\text { de formación técnica o deficitaria y se } \\
\text { dictan otras disposiciones. }\end{array}$ & Educación \\
\hline Ley & 1324 & $\begin{array}{l}\text { Congreso de la } \\
\text { República }\end{array}$ & 2009 & $\begin{array}{l}\text { Fija parámetros y criterios para organi- } \\
\text { zar el sistema de evaluación de resul- } \\
\text { tados de la calidad de la educación. } \\
\text { Establece principio de equidad en la } \\
\text { presentación de las pruebas de Estado. }\end{array}$ & Educación \\
\hline Decreto & 366 & $\begin{array}{l}\text { Presidenciade la } \\
\text { República }\end{array}$ & 2009 & $\begin{array}{l}\text { Reglamenta la organización del servicio } \\
\text { de apoyo pedagógico para la atención } \\
\text { de los estudiantes con discapacidad y } \\
\text { con capacidades o talentos excepcio- } \\
\text { nales en el marco de la educación in- } \\
\text { clusiva. }\end{array}$ & Educación \\
\hline
\end{tabular}


Tabla 10. Legislación en discapacidad. Ámbito nacional. Accesibilidad física.

\begin{tabular}{|c|c|c|c|c|c|}
\hline Tipo & No & Expedida por & Año & $\begin{array}{c}\text { Nombre } \\
\text { Descripción de la norma }\end{array}$ & Tema \\
\hline Ley & 12 & $\begin{array}{l}\text { Congreso de la } \\
\text { República }\end{array}$ & 1987 & $\begin{array}{l}\text { Se suprimen algunas barreras arqui- } \\
\text { tectónicas y se dictan otras disposi- } \\
\text { ciones. }\end{array}$ & Accesibilidad \\
\hline Ley & 105 & $\begin{array}{l}\text { Congreso de la } \\
\text { República }\end{array}$ & 1993 & $\begin{array}{l}\text { Disposiciones básicas del transporte. } \\
\text { Art. } 3 \text { principios de acceso incluyen- } \\
\text { do personas con discapacidad. }\end{array}$ & $\begin{array}{l}\text { Accesibilidad } \\
\text { (Transporte) }\end{array}$ \\
\hline Ley & 361 & $\begin{array}{l}\text { Congreso de la } \\
\text { República }\end{array}$ & 1997 & $\begin{array}{l}\text { Establece mecanismos de integra- } \\
\text { ción social de las personas con } \\
\text { limitación y se dictan otras disposi- } \\
\text { ciones. }\end{array}$ & $\begin{array}{l}\text { Integración } \\
\text { social }\end{array}$ \\
\hline Decreto & 1504 & $\begin{array}{l}\text { Presidencia de la } \\
\text { República }\end{array}$ & 1998 & $\begin{array}{l}\text { Reglamenta el manejo del espacio } \\
\text { público en los planes de ordena- } \\
\text { miento territorial. }\end{array}$ & $\begin{array}{l}\text { Accesibilidad } \\
\text { (espacios) }\end{array}$ \\
\hline Decreto & 1660 & $\begin{array}{l}\text { Ministerio de } \\
\text { Transporte }\end{array}$ & 2003 & $\begin{array}{l}\text { Reglamenta la accesibilidad en los } \\
\text { modos de transporte de la población } \\
\text { en general y en especial de las per- } \\
\text { sonas con discapacidad. }\end{array}$ & $\begin{array}{l}\text { Accesibilidad } \\
\text { (Transporte) }\end{array}$ \\
\hline Decreto & 975 & $\begin{array}{l}\text { Ministerio de } \\
\text { Ambiente, Vivienda } \\
\text { y Desarrollo } \\
\text { Territorial }\end{array}$ & 2004 & $\begin{array}{l}\text { Facilita el acceso de las personas con } \\
\text { discapacidad al Subsidio Familiar de } \\
\text { Vivienda de Interés Social. }\end{array}$ & $\begin{array}{l}\text { Discapacidad - } \\
\text { Vivienda }\end{array}$ \\
\hline Decreto & 1538 & $\begin{array}{l}\text { Ministerio de } \\
\text { Ambiente, Vivienda } \\
\text { y Desarrollo } \\
\text { Territorial }\end{array}$ & 2005 & $\begin{array}{l}\text { Reglamenta parcialmente la Ley } 361 \\
\text { de } 1997 \text { para establecer las condi- } \\
\text { ciones básicas de accesibilidad al } \\
\text { espacio público y la vivienda. }\end{array}$ & $\begin{array}{l}\text { Accesibilidad } \\
\text { (Vivienda) }\end{array}$ \\
\hline Decreto & 2190 & $\begin{array}{l}\text { Ministerio de } \\
\text { Ambiente, Vivienda } \\
\text { y Desarrollo } \\
\text { Territorial }\end{array}$ & 2009 & $\begin{array}{l}\text { Reglamentado por resolución } 1604 \\
\text { de } 2009 \text {. Establece subsidio familiar } \\
\text { de vivienda de interés social en la } \\
\text { modalidad de mejoramiento para } \\
\text { vivienda saludable. }\end{array}$ & $\begin{array}{l}\text { Discapacidad - } \\
\text { Vivienda }\end{array}$ \\
\hline Ley & 1287 & $\begin{array}{l}\text { Congreso de la } \\
\text { República }\end{array}$ & 2009 & $\begin{array}{l}\text { Por la cual se adiciona la ley } 361 \text { de } \\
\text { 1997, bahías de estacionamiento } \\
\text { para personas con movilidad redu- } \\
\text { cida. }\end{array}$ & Accesibilidad \\
\hline Ley & 1316 & $\begin{array}{l}\text { Congreso de la } \\
\text { República }\end{array}$ & 2009 & $\begin{array}{l}\text { Por medio de la cual se reforma par- } \\
\text { cialmente la Ley } 361 \text { de } 1997 \text {, se re- } \\
\text { conoce un espacio en los espectácu- } \\
\text { los para personas con discapacidad } \\
\text { y se dictan otras disposiciones. }\end{array}$ & Accesibilidad \\
\hline
\end{tabular}

con discapacidad, dan especial relevancia a la participación en todos los espacios de la vida cotidiana. Si bien en la normatividad colombiana en discapacidad no es encuentran muchas referencias a aspectos relacionados con la participación en la actividad física, el deporte, la recreación y la cultura, cabe destacar los ejemplos incluidos en las tablas 12 y 13 , en la medida que muestran avances en el camino de abordar los derechos de esta población más allá de la mirada asistencial. 
Tabla 11. Legislación en discapacidad. Ámbito nacional. Comunicación.

\begin{tabular}{|c|c|c|c|c|c|}
\hline Tipo & No & Expedida por & Año & $\begin{array}{c}\text { Nombre } \\
\text { Descripción de la norma }\end{array}$ & Tema \\
\hline Acuerdo & 38 & $\begin{array}{l}\text { Comisión } \\
\text { Nacional de } \\
\text { Televisión }\end{array}$ & 1988 & $\begin{array}{l}\text { Crea mecanismos para garantizar el } \\
\text { acceso al servicio público de televi- } \\
\text { sión por parte de las personas con } \\
\text { limitación auditiva. }\end{array}$ & $\begin{array}{l}\text { Comunicaciones/ } \\
\text { sordos }\end{array}$ \\
\hline Ley & 335 & $\begin{array}{l}\text { Congreso de la } \\
\text { República }\end{array}$ & 1996 & $\begin{array}{l}\text { Crea la televisión privada, Art. } 12 \\
\text { "...Se deberá incluir el sistema de } \\
\text { subtitulación o lengua manual para } \\
\text { garantizar el acceso de este servicio } \\
\text { a las personas con problemas auditi- } \\
\text { vos o sordas". }\end{array}$ & $\begin{array}{l}\text { Comunicaciones/ } \\
\text { sordos usuarios de } \\
\text { lengua de señas } \\
\text { colombiana (LSC) }\end{array}$ \\
\hline Decreto & 672 & $\begin{array}{l}\text { Ministerio de } \\
\text { Educación } \\
\text { Nacional }\end{array}$ & 1998 & $\begin{array}{l}\text { Modifica el artículo } 13 \text { del decreto } \\
2369 \text { de } 2007 \text { sobre comunicación } \\
\text { en lengua de señas para personas } \\
\text { sordas. }\end{array}$ & $\begin{array}{l}\text { Comunicaciones/ } \\
\text { sordos usuarios } \\
\text { de LSC }\end{array}$ \\
\hline Decreto & 1130 & $\begin{array}{l}\text { Presidencia } \\
\text { de la República }\end{array}$ & 1999 & $\begin{array}{l}\text { Reestructura el Ministerio de Comu- } \\
\text { nicaciones. La información como } \\
\text { derecho fundamental, las telecomu- } \\
\text { nicaciones tienen por objeto elevar } \\
\text { el nivel de vida de los habitantes, } \\
\text { las comunicaciones deben tener } \\
\text { un uso y beneficio social, y se debe } \\
\text { desarrollar investigación y nuevas } \\
\text { tecnologías. }\end{array}$ & Comunicaciones \\
\hline Resolución & 161 & $\begin{array}{l}\text { Comisión de } \\
\text { Regulación de } \\
\text { Telecomunica- } \\
\text { ciones }\end{array}$ & 1999 & $\begin{array}{l}\text { Promueve el servicio universal a } \\
\text { través de teléfonos públicos para } \\
\text { discapacitados. }\end{array}$ & Comunicaciones \\
\hline Resolución & 1080 & $\begin{array}{l}\text { Ministerio de } \\
\text { comunicaciones }\end{array}$ & 2002 & $\begin{array}{l}\text { Fija los criterios aplicables a la pro- } \\
\text { gramación de televisión para la po- } \\
\text { blación sorda. }\end{array}$ & $\begin{array}{l}\text { Comunicaciones/ } \\
\text { sordos }\end{array}$ \\
\hline
\end{tabular}

Tabla 12. Legislación en discapacidad. Ámbito nacional. Cultura y discapacidad.

\begin{tabular}{|c|c|c|c|c|c|}
\hline Tipo & No & Expedida por & Año & Nombre - Descripción de la norma & Tema \\
\hline Ley & 397 & $\begin{array}{l}\text { Congreso de la } \\
\text { República }\end{array}$ & 1997 & $\begin{array}{l}\text { Dicta normas sobre el patrimonio cultural, } \\
\text { fomentos y estímulos de la cultura, se crea } \\
\text { el Ministerio de la Cultura."El Estado, al for- } \\
\text { mular la política cultural tendrá en cuenta } \\
\text { y concederá especial tratamiento a las per- } \\
\text { sonas limitadas física, sensorial y psíquica- } \\
\text { mente...". En los Consejos nacional, depar- } \\
\text { tamentales, distritales y municipales, habrá } \\
\text { un representante de las agremiaciones cul- } \\
\text { turales de discapacitados físicos, psíquicos } \\
\text { y sensoriales. }\end{array}$ & Cultura \\
\hline Ley & 1237 & $\begin{array}{l}\text { Congreso de la } \\
\text { República }\end{array}$ & 2008 & $\begin{array}{l}\text { Promueve, fomenta y difunde las habilida- } \\
\text { des, talentos y las manifestaciones artísticas } \\
\text { y culturales de la población con algún tipo } \\
\text { de limitación física, psíquica o sensorial. }\end{array}$ & Cultura \\
\hline
\end{tabular}


Tabla 13. Legislación en discapacidad. Ámbito nacional. Deporte y discapacidad.

\begin{tabular}{|c|c|c|c|c|c|}
\hline Tipo & No & Expedida por & Año & Nombre - Descripción de la norma & Tema \\
\hline Ley & 181 & $\begin{array}{l}\text { Congreso de la } \\
\text { República }\end{array}$ & 1995 & $\begin{array}{l}\text { Ley para el fomento del deporte, la re- } \\
\text { creación, el aprovechamiento del tiempo } \\
\text { libre y la educación física. Especifica la } \\
\text { creación de programas y acciones para la } \\
\text { participación de personas en situación de } \\
\text { discapacidad. }\end{array}$ & Deporte \\
\hline Decreto & 2080 & $\begin{array}{l}\text { Ministerio de } \\
\text { Educación } \\
\text { Nacional }\end{array}$ & 1996 & $\begin{array}{l}\text { Reglamenta la Federación Paralímpica. } \\
\text { Derogado por el Decreto } 582 \text { de } 2000 .\end{array}$ & Deporte \\
\hline Ley & 582 & $\begin{array}{l}\text { Congreso de la } \\
\text { República }\end{array}$ & 2000 & $\begin{array}{l}\text { Establece el Sistema Deportivo Nacional } \\
\text { de las Personas con Discapacidad y crea el } \\
\text { Comité Paraolímpico Colombiano como } \\
\text { máximo ente rector, organiza por modali- } \\
\text { dad de discapacidad cada una de las fede- } \\
\text { raciones deportivas. }\end{array}$ & Deporte \\
\hline Decreto & 641 & $\begin{array}{l}\text { Presidencia de la } \\
\text { República }\end{array}$ & 2001 & $\begin{array}{l}\text { Reglamenta la Ley } 582 \text { de } 2000 \text { sobre de- } \\
\text { porte asociado de personas con limitacio- } \\
\text { nes físicas, mentales o sensoriales. }\end{array}$ & Deporte \\
\hline Resolución & 741 & Coldeportes & 2005 & $\begin{array}{l}\text { Reglamenta el Programa "Apoyo al Depor- } \\
\text { tista Paralímpico Colombiano". }\end{array}$ & Deporte \\
\hline Ley & 1389 & $\begin{array}{l}\text { Congreso de la } \\
\text { República }\end{array}$ & 2010 & $\begin{array}{l}\text { Por la cual se establecen incentivos para } \\
\text { los deportistas y se reforman algunas dis- } \\
\text { posiciones de la normatividad deportiva. }\end{array}$ & Deporte \\
\hline Resolución & 0351 & $\begin{array}{l}\text { Ministerio de } \\
\text { Cultura } \\
\text { Coldeportes }\end{array}$ & 2011 & $\begin{array}{l}\text { Por la cual se reglamentan los incentivos } \\
\text { para deportistas y entrenadores, conforme } \\
\text { lo establece la Ley } 1389 \text { de } 2010 .\end{array}$ & Deporte \\
\hline
\end{tabular}

\section{Conclusiones}

La legislación colombiana en materia de discapacidad se ha centrado históricamente en la provisión de asistencia (rehabilitación, oferta de apoyos técnicos, intervenciones quirúrgicas) a las personas en esta condición, lo cual se hace con un enfoque individual, es decir, bajo la mirada de la discapacidad centrada en el individuo ( $y$ en sus deficiencias) y por lo tanto, como algo que debe ser resuelto desde la intervención en el cuerpo para mejorar su funcionamiento.

Lo anterior se ve reflejado incluso en la existencia y funcionamiento de un Sistema Nacional de Discapacidad, creado por Ley 1145 de 2007, como el "mecanismo de coordina- ción de los diferentes actores que intervienen en la integración social de esta población en el marco de los derechos humanos" (Art. 5) y cuyo ente rector es el Ministerio de Protección Social (Art. 8).

Este es uno de los temas ampliamente discutidos por las organizaciones de personas con discapacidad, quienes insisten en la necesidad de un cambio en el enfoque que debe provenir desde las misma estructura del Sistema, ya que la perspectiva de salud sigue siendo evidente en las decisiones institucionales que se desprenden de los manuales de calificación de la discapacidad y se reflejan en la construcción de planes y programas y la destinación de presupuestos, los cuales se invierten en proyectos de 
provisión de ayudas técnicas y servicios de rehabilitación sin alcanzar mayor impacto social. Las propuestas de tipo social son necesarias y relevantes para lograr la plena inclusión en la sociedad, pero a éstas se les da poca atención. De lo anterior da cuenta la ausencia de una política pública en discapacidad en el país y la escasa operatividad del Consejo Nacional de la Discapacidad.

No obstante con la reciente ratificación de la Ley 1346 de 2009, por la cual se adopta la Convención sobre los derechos de las personas con Discapacidad, la población con discapacidad cuenta con un valioso recurso jurídico, que supera ampliamente la normatividad existente. La Convención representa un gran avance en la comprensión de la discapacidad como el resultado de la relación entre los individuos y el entorno en el cual se desenvuelven, y de este último como potencialmente discapacitante, aspectos que han venido reflejándose en la normatividad internacional y nacional, no solo en la expedición de normas más allá de la atención en salud, sino también en la ampliación y evolución de conceptos, en el lenguaje utilizado para las mismas, los ajustes razonables para garantizar la accesibilidad, el reconocimiento de las personas con discapacidad como sujetos de derechos y finalmente, lograr su participación e incorporación progresiva, si bien aún con restricciones, en la sociedadEs necesario implementar acciones para fortalecer y acelerar las transformaciones en todos los espacios, e incursionar apoyándose en los recursos que ofrece la Constitución y la amplia normativa para la ruptura de las barreras actitudinales, promovien- do de esta manera, la cohesión social, y la participación de las personas con discapacidad en todas las esferas de la vida cotidiana, a través de su empoderamiento y un rol protagónico en la defensa, promoción y protección de sus derechos, como una manera de lograr su realización individual, el disfrute de la vida y del bienestar.

Finalmente en lo referente al ámbito jurídico, es pertinente avanzar en la revisión y modificaciones a la normativa existente, con el propósito de hacerla acorde con los principios trazados por la Convención desde el enfoque de los Derechos Humanos.

"Las respuestas sociales ante problemas de salud tampoco se restringen a las acciones de las instituciones de salud, sino que involucran el acceso a oportunidades de vida y a la distribución equitativa de los beneficios del desarrollo con justicia social y solidaridad". (Cruz, 2005, p. 95).

\section{Referencias}

Coldeportes (2005). Resolución 741 de 2005. Recuperado de http://www.cnsc. gov.co/docs/3.3.23.2.400.pdf

Comisión de Regulación de Telecomunicaciones (1999). Resolución 161 de 1999. Recuperado de http://www.crcom.gov. co/index.php?idcategoria $=61313 \#$

Comisión Nacional de Televisión (1988). Acuerdo 38 de 1988. Recuperado de http://www.alcaldiabogota.gov.co/sisjur/ normas/Norma1.jsp? $i=15012$

Conferencia Intergubernamental Iberoamericana sobre Políticas para Personas Ancianas y Personas Discapacitadas. Declaración de Cartagena de Indias sobre políticas integrales para las personas con discapacidad en el área Iberoamericana. Recuperado de http://www.cnree.go.cr/ sobre-discapacidad/legislacion/45-declaracion-de-cartagena-de-indias-sobre- 
politicas-integrales-para-las-personascon-discapacidad-en-el-area-iberoamericana.html

Congreso de la República de Colombia (1968). Ley 74 de 1968. Recuperado de http://www.observatorioddr.unal.edu. co/ambitojuridico/catalogo_juridicojyp/ ley_74_de_1968.pdf

Congreso de la República de Colombia (1987). Ley 12 de 1987. Recuperado de http://www.alcaldiabogota.gov.co/sisjur/ normas/Norma1.jsp?i=14932

Congreso de la República de Colombia (1988). Ley 82 de 1988. Recuperado de http://www.alcaldiabogota.gov.co/sisjur/ normas/Norma1.jsp?i=14931

Congreso de la República de Colombia (1993). Ley 100 de 1993. Recuperado de http://www.secretariasenado.gov.co/senado/basedoc/ley/1993/ley_0100_1993. html

Congreso de la República de Colombia (1993). Ley 105 de 1993. Recuperado de http://www.alcaldiabogota.gov.co/sisjur/normas/Norma1.jsp?i=296

Congreso de la República de Colombia (1994). Ley 115 de 1994: Ley General de Educación. Recuperado de http:// www.mineducacion.gov.co/1621/articles-85906_archivo_pdf.pdf

Congreso de Ta República de Colombia (1995). Ley 181 de 1995. Recuperado de http://www.coldeportes.gov.co/coldeportes/index.php?idcategoria $=48993$

Congreso de la República de Colombia (1996). Ley 324 de 1996. Recuperado de http://www.alcaldiabogota.gov.co/sisjur/normas/Norma1.jsp? $i=349$

Congreso de la República de Colombia (1996). Ley 335 de 1996. Recuperado de http://www.secretariasenado.gov.co/senado/basedoc/ley/1996/ley_0335_1996. html

Congreso de la República de Colombia (1997). Ley 361 de 1997. Recuperado de http://www.alcaldiabogota.gov.co/sisjur/normas/Norma1.jsp?i=343

Congreso de la República de Colombia (1997). Ley 397 de 1997: Ley General de Cultura. Recuperado de http://www.mincultura.gov.co/index. php?idcategoria $=6546 \#$
Congreso de la República de Colombia (1988). Ley 82 de 1988. Recuperado de http://www.alcaldiabogota.gov.co/sisjur/ normas/Norma1.jsp?i=14931

Congreso de la República de Colombia (1998). Ley 443 de 1998. Recuperado de http://www.alcaldiabogota.gov.co/sisjur/normas/Norma1.jsp?i=190

Congreso de la República de Colombia (2000). Ley 582 de 2000. Recuperado de http://www.mineducacion.gov.co/1621/ articles-86067 archivo pdf.pdf

Congreso de la República de Colombia (2001). Ley 643 de 2001. Recuperado de http://www.secretariasenado.gov.co/senado/basedoc/ley/2001/ley_0643_2001. html

Congreso de la República de Colombia (2002). Ley 762 de 2002. Recuperado de http://www.secretariasenado.gov.co/senado/basedoc/ley/2002/ley_0762_2002. html

Congreso de la República de Colombia (2005). Ley 982 de 2005. Recuperado de http://www.secretariasenado.gov.co/senado/basedoc/ley/2005/ley_0982_2005. html

Congreso de la República de Colombia (2006). Ley 1098 de 2006: Código de infancia y adolescencia. Recuperado de http://www.secretariasenado.gov.co/senado/basedoc/ley/2006/ley_1098_2006. html

Congreso de la República de Colombia (2007). Ley 1145 de 2007. Recuperado de http://www.secretariasenado.gov.co/senado/basedoc/ley/2007/ ley_1145_2007.html

Congreso de la República de Colombia (2008). Ley 1237 de 2008. Recuperado de http://www.secretariasenado.gov.co/senado/basedoc/ley/2008/ ley_1237_2008.html

Congreso de la República de Colombia (2009). Ley 1275 de 2009. Recuperado de http://www.secretariasenado.gov.co/senado/basedoc/ley/2009/ ley_1275_2009.html

Congreso de la República de Colombia (2009). Ley 1287 de 2009. Recuperado de http://www.secretariasena 
do.gov.co/senado/basedoc/ley/2009/ ley_1287_2009.html

Congreso de la República de Colombia (2009). Ley 1297 de 2009. Recuperado de http://www.mineducacion.gov. co/1621/articles-191904_archivo_pdf_ ley1297.pdf

Congreso de la República de Colombia (2009). Ley 1306 de 2009. Recuperado de http://www.secretariasenado.gov.co/senado/basedoc/ley/2009/ ley 1306 2009.html

Congreso de la República de Colombia (2009). Ley 1316 de 2009. Recuperado de http://www.secretariasenado.gov.co/senado/basedoc/ley/2009/ ley_1316_2009.html\#Inicio.

Congreso de la República de Colombia (2009). Ley 1324 de 2009. Recuperado de http://www.mineducacion.gov. co/1621/articles-210697_archivo_pdf_ ley_1324.pdf

Congreso de la República de Colombia (2009). Ley 1346 de 2009. Recuperado de http://www.secretariasenado.gov.co/senado/basedoc/ley/2009/ ley_1346_2009.html

Congreso de la República de Colombia (2010). Ley 1389 de 2010. Recuperado de http://www.secretariasenado.gov.co/senado/basedoc/ley/2010/ ley_1389_2010.html

Consejería Presidencial de Programa Especiales. (2012). Apoyo a la discapacidad: Legislación en discapacidad. Recuperado de http://cppe.presidencia.gov.co/ Home/apoyo/Paginas/legislacion_discapacidad.aspx

Consejo Nacional de Seguridad Social en Salud (1997). Acuerdo 72 de 1997. Recuperado de http://www.alcaldiabogota.gov.co/sisjur/normas/Norma1. jsp? $\mathrm{i}=4712$

Consejo Nacional de Seguridad Social en Salud (1997). Acuerdo 77 de 1977. Recuperado de http://www.alcaldiabogota.gov.co/sisjur/normas/Norma1. jsp? $i=4712$

Correa Montoya, L. (2009). Panorama de la protección jurisprudencial a los humanos de las personas con discapacidad en Colombia. Vniversitas, 118, 115-139. Recuperado de http://www.scielo.org.co/scie- lo.php?script $=$ sci_arttext $\&$ pid $=$ S0041$90602009000100005 \& \operatorname{lng}=\mathrm{es} \& \mathrm{nrm}=$ is o\#nu3

Covadonga, M. (2011). La Convención sobre los derechos de las personas con discapacidad herramienta clave para la inclusión. Documento inédito. Síntesis de conferencia. Bogotá: Universidad Nacional de Colombia, Dirección Nacional de Bienestar Universitario.

Cruz Velandia, Israel. (2005). La salud colectiva y la inclusión social de las personas con discapacidad. Revista Investigación y Educación en Enfermería, 23 (1), 95100. Recuperado de http://aprendeenlinea.udea.edu.co/revistas/index.php/iee/ article/viewFile/2952/2639

Departamento Nacional de Planeación (1999). Plan nacional de atención a las personas con discapacidad 1999 [ 2002. Recuperado de http://books.google.com.co/books/about/Plan_nacional de atenci\%C3\%B3n a las persona. html $? \overline{i d}=$ 9BHAAAAYAAJ \& $\overline{\text { redir }}$ esc $=y$

Departamento Nacional de Planeación (2002). Plan nacional de discapacidad 2002 - 2006. Recuperado de http://www.urosario.edu.co/urosario files/12/12e61953-332f-4fc3-97d79d解286c7c22e.pdf

Departamento Nacional de Planeación (2004). CONPES 80: Política pública de discapacidad. Recuperado de http://www.mincultura.gov. $\mathrm{co} /$ ? idcategoria $=7373$

Gómez, C. \& Cuervo, C. (2007). Conceptualización de discapacidad: Reflexiones para Colombia. Bogotá: Universidad Nacional de Colombia, Facultad de Medicina.

Icontec \& Ministerio de Educación Nacional (1999). Norma técnica colombiana 4596. Recuperado de http://www.mineducacion.gov.co/cvn/1665/articles-96894_ Archivo_pdf.pdf

Icontec (1999). NTC 4732: Muebles escolares. Pupitre y silla para alumnos con limitaciones físicas. Parálisis cerebral. Bogotá: Icontec.

Icontec (1999). NTC 4733: Muebles escolares. Pupitre para alumnos en silla de ruedas. Bogotá: Icontec. 
Icontec \& Ministerio de Educación Nacional (2006). Norma técnica colombiana 4595: Planeamiento y diseño de instalaciones y ambientes escolares. Recuperado de http:// www.mineducacion.gov.co/cvn/1665/articles-96894_Archivo_pdf.pdf

Icontec \& Ministerio de Educación Nacional (2006). Norma técnica colombiana 4596: Señalización para instalaciones y ambientes escolares. Recuperado de http:// www.mineducacion.gov.co/cvn/1665/ articles-96894 Archivo pdf.pdf

Ministerio de Ambiente, Vivienda y Desarrollo Territorial (2004). Decreto 975 de 2004. Recuperado de http://www. acnur.org/t3/fileadmin/scripts/doc. php?file $=$ biblioteca $/$ pdf $/ 5620$

Ministerio de Ambiente, Vivienda y Desarrollo Territorial (2005). Decreto 1538 de 2005. Recuperado de http://www.alcaldiabogota.gov.co/sisjur/normas/Norma1. jsp? $\mathrm{i}=16540$

Ministerio de Ambiente, Vivienda y Desarrollo Territorial (2009). Decreto 2190 de 2009. Recuperado de http://www.alcaldiabogota.gov.co/sisjur/normas/Norma1. jsp? $\mathrm{i}=36468 \# 96$.

Ministerio de Comunicaciones (2002). Resolución 1080 de 2002. Recuperado de https://www.icbf.gov.co/transparencia/ derechobienestar/resolucion/resolucion mincomunicaciones 1080 2002.html

Ministerio de Cultura (2011). Resolución 351 de 2011. Recuperado de http://www.coldeportes.gov.co/ coldeportes/?idcategoria $=53539 \#$

Ministerio de Educación Nacional (1996). Decreto 2080 de 1996. Recuperado de http://www.alcaldiabogota.gov.co/sisjur/ normas/Norma1.jsp? $\mathrm{i}=10814$

Ministerio de Educación Nacional (1998). Decreto 672 de 1998. Recuperado de http://www.alcaldiabogota.gov.co/sisjur/ normas/Norma1.jsp? $\mathrm{i}=10812$

Ministerio de Educación Nacional (1998). Decreto 1509 de 1998. Recuperado de http://www.presidencia.gov.co/prensa_new/decretoslinea/1998/agosto/04/ dec1509041998.pdf

Ministerio de Educación Nacional (2003). Resolución 2565 de 2003. Recuperado de http://www.mineducacion.gov. co/1621/articles-85960_archivo_pdf.pdf
Ministerio de Relaciones Exteriores (2001). Decreto 429 de 2001. Recuperado de https://www.icbf.gov.co/transparencia/derechobienestar/decreto/decreto 0429 2001.html

Ministerio de Salud (1985). Resolución 14861 de 1985. Recuperado de http://190.41.250.173/RIJ/BASES/pcd/ C14861.htm

Ministerio de Salud (1994). Resolución 5261 de 1994. Recuperado de www.pos.gov. $\mathrm{co} / . . . /$ resolucion 5261 de 1994.pdf

Ministerio de Salud (1996). Decreto 2226 de 1996. Recuperado de http://www.alcaldiabogota.gov.co/sisjur/normas/Norma1. jsp? $\mathrm{i}=10810$

Ministerio de Salud (1996). Resolución 3165 de 1996. Recuperado de http://www. saludcapital.gov.co/Documentos $\% 20$ Discapacitados/Reh\%20Institucional/ rehabilitaci\%C3\%B3n\%20en\%20el\%20 POSS.pdf

Ministerio de Salud (1998). Resolución 2178 de 1998. Recuperado de http://www. epssura.com/index.php?option $=$ com content\&view $=$ article\&id = 783: resoluc ion-2178-1998\&catid=91: resoluciones \&ltemid $=415$

Ministerio de Salud (1999). Resolución 238 de 1999. Recuperado de www.esevictoria.gov.co/.../index.php?...RESOLU$\mathrm{CION} \%$...

Ministerio de Salud (2000). Decreto 276 de 2000. Recuperado de http://www.alcaldiabogota.gov.co/sisjur/normas/Norma1. jsp? $i=6056$

Ministerio de Trabajo y Seguridad Social (1995). Decreto 692 de 1995: Manual único de calificación de invalidez. Recuperado de http://www.alcaldiabogota.gov.co/sisjur/normas/Norma1. jsp?i=14928

Ministerio de Trabajo y Seguridad Social (1999). Decreto 1128 de 1999. Recuperado de http://www.presidencia.gov. co/prensa_new/decretoslinea/1999/junio/29/dec1128291999.pdf

Ministerio de Transporte (2003). Decreto 1660 de 2003. Recuperado de http:// www.alcaldiabogota.gov.co/sisjur/normas/Norma1.jsp? $i=8799$

Moreno Angarita, M. (2007). Políticas y concepciones en discapacidad: un binomio 
por explorar. Bogotá: Universidad Nacional de Colombia. Facultad de Medicina.

OEA (1999). Convención interamericana para la eliminación de todas las formas de discriminación contra las personas con discapacidad. Recuperado de http://www.oas.org/Juridico/spanish/ tratados/a-65.html

OEA (2000). Resolución 369, Declaración de Panamá: La discapacidad un asunto de derechos humanos. Recuperado de http://www.inclusion-ia.org/espa\%F1ol/ Norm/compromiso panama.htm

OIT (1955). Recomendación 99 sobre la adaptación y la readaptación profesionales de los inválidos. Recuperado de http:/www.ilo.org/dyn/normlex/es/ $f ? p=1000: 12100: 0:: N O:: P 12100$ INSTRUMENT ID:312437

OIT (1958). Convenio 111 sobre la discriminación (empleo y ocupación). Recuperado de http://www.ilo.org/dyn/normlex/ $\mathrm{es} / \mathrm{f} ? \mathrm{p}=1000: 12100: 0:: \mathrm{NO}:: \mathrm{P} 12100_{-}$ INSTRUMENT ID:312256

OIT (1975). Recomendación 150 sobre desarrollo de los recursos humanos. Recuperado de http://www.ilo.org/dyn/normlex/ es/f?p=1000:12100:0::NO::P12100 INSTRUMENT_ID:312488

OIT (1983). Convenio 159 sobre la readaptación profesional y el empleo de personas inválidas. Recuperado de http://www. oit.org.pe/index.php?option $=$ com_co ntent\&view $=$ article\&id =2074: conven io-159\&catid = 298: instrumentos-jurcosoit\&Itemid $=1366$

OIT (1983). Recomendación 168 sobre la readaptación profesional y el empleo de personas inválidas. Recuperado de http://www.ilo.org/dyn/normlex/es/ $f ? p=1000: 12100: 0::$ NO::P12100_INSTRUMENT ID:312506

OMS (2001). C̄lasificación Internacional del Funcionamiento, la Discapacidad y la Salud (CIF). Recuperado de http://www. imsersomayores.csic.es/documentos/documentos/oms-clasificacion-02.pdf

ONU (1948). Declaración Universal de los Derechos Humanos. Recuperado de http://www.un.org/es/documents/udhr/

ONU (1971). Declaración del los Derechos del Retrasado Mental. Recuperado de http://www.cinu.org.mx/temas/desarroIlo/dessocial/integracion/ares2856xxvi. htm

ONU (1975). Declaración de los derechos de los impedidos. Recuperado de http:// cd3.uniandes.edu.co/sistema_derechos_humanos/sistemas_principales/ sistema_universal/documentos/tratados/ declaracion_de_los_derechos_de_los_ impedidos

ONU (1979). Declaración sobre los derechos de las Personas Sordo-Ciegas. Recuperado de http://www1.umn.edu/humanrts/ instree/deaf-blindrights.html

ONU (1982). Resolución 37/52. Disponible en http://www.inclusion-ia.org/ espa\%F1ol/Norm/Res37-52.htm

ONU (1993). Declaración y Programa de Acción de Viena. Recuperado de http:// www.unhchr.ch/huridocda/huridoca. nsf/\%28Symbol\%29/A.CONF.157.23.Sp

ONU (1993). Resolución 48/96, Normas uniformes sobre la igualdad de oportunidades para las personas con discapacidad. Recuperado de http://www.minproteccionsocial.gov.co/discapacidad/normasuniformes.doc

ONU (2001). Convención internacional amplia e integral para la protección y promoción de los derechos y la dignidad de las personas con discapacidad. Recuperado de: http://www.icrpd.net/ratification/documents/sp/Extras/General\%20 Assembly\%20Res\%2056\%20168.pdf

OPS \& OMS (2004). Declaración de Montreal sobre la discapacidad intelectual. Recuperado de http://www.conferencemontreal2004paho-who.com/espagnol/ declaracion.htm

Osorno P., M. L. (2009). Legislación/ Normatividad. Informe de trabajo, Sistema de Inclusión Educativa. Documento inédito. Bogotá: Universidad Nacional de Colombia.

Presidencia de la República (1981). Decreto 2358 de 1981. Recuperado de http:// periodicoproclama.org/page.php?mod $=$ czoxNjoiY3pvME9pSnVaWGR6SWp zPSI7 \&accion $=$ view $\&$ st $=1 \&$ sec $=66 \&$ $\mathrm{id}=249$

Presidencia de la República (1989). Decreto 2737 de 1989: Código del menor. Recu- 
perado de http://www.secretariasenado. gov.co/senado/basedoc/codigo/codigo_ menor_pr005.html

Presidencia de la República (1989). Ley 2177 de 1989. Recuperado de http:// www.alcaldiabogota.gov.co/sisjur/normas/Norma1.jsp? $i=10813$

Presidencia de la República de Colombia (1993). Decreto Ley 2381 de 1993. Recuperado de http://www.alcaldiabogota.gov.co/sisjur/normas/Norma1. jsp?i=10788

Presidencia de la República (1994). Decreto 369 de 1994. Recuperado de http:// www.alcaldiabogota.gov.co/sisjur/normas/Norma1.jsp?i=14929

Presidencia de la República (1994). Decreto 970 de 1994. Recuperado de http:// www.alcaldiabogota.gov.co/sisjur/normas/Norma1.jsp?i=4939

Presidencia de la República (1996). Decreto 2082 de 1996. Recuperado de http://fundacionexe.org.co/wp-content/uploads/2011/09/decreto-2082de-1996.pdf

Presidencia de la República (1997). Decreto 2369 de 1997. Recuperado de http:// www.alcaldiabogota.gov.co/sisjur/normas/Norma1.jsp? $i=1203$

Presidencia de la República (1997). Decreto 3011 de 1997. Recuperado de http:// www.mineducacion.gov.co/1621/articles-86207_archivo_pdf.pdf

Presidencia de la República (1998). Decreto 672 de 1998. Recuperado de http://201.244.4.20:8080/homepage/ALEGIS_INTER/LEYES_Y_DECRETOS/1998/DECRETO_672_DE_DE_1998. pdf

Presidencia de la República (1998). Decreto 1504 de 1998. Recuperado de http:// www.alcaldiabogota.gov.co/sisjur/normas/Norma1.jsp?i=1259

Presidencia de la República (1999). Decreto 917 de 1999. Recuperado de http:// www.alcaldiabogota.gov.co/sisjur/normas/Norma1.jsp? $\mathrm{i}=29544 \# 16$
Presidencia de la República (1999). Decreto 1130 de 1999. Recuperado de http:// www.sic.gov.co/siyc/memoria/decreto/1999/decreto 1130 1999.html

Presidencia de la Rēpública (2001). Decreto 641 de 2001. Recuperado de www. alcaldiabogota.gov.co/sisjur/normas/Norma1.jsp?i=4825

Presidencia de la República (2009). Decreto 366 de 2009. Recuperado de http://www.mineducacion.gov.co/1621/ articles-182816 archivo pdf decreto 366 febrero 9 2009.pdf

República de Colombia (1991). Constitución Política de Colombia. Recuperado de http://www.banrep.gov.co/regimen/ resoluciones/cp91.pdf

UNESCO (1990). Declaración mundial sobre educación para todos: Satisfacción de las necesidades básicas de aprendizaje. Recuperado de http://unesdoc.unesco.org/ images/0012/001275/127583s.pdf

UNESCO (1994). Declaración de Salamanca y marco de acción para las necesidades educativas especiales. Recuperado de http://www.mineduc.cl/usuarios/edu. especial/File/DOCUMENTOS\%202010/ DeclaraciOndeSalamanca.pdf

UNESCO (2000). Educación para todos en las Américas: Marco de acción regional. Recuperado de http://www.unesco.org/ education/wef/en-leadup/regmeet_frame_ameri.shtm

Vicepresidencia de la República (1995). Conpes 2761: Política de prevención y atención a las personas con discapacidad. Recuperado de http://www.jairoclopatofsky.com/docs/documentos/COMPENDIO_NORMAS_DISCPACIDAD.pdf

Marco Legal de la Discapacidad. Recuperado de http://www.dane.gov.co/files/investigaciones/discapacidad/marco_legal. pdf 